\title{
Testemunho, violência, arte
}

\author{
Adriano Schwartz
}

Penna, João Camillo. Escritos da sobrevivência. Rio de Janeiro: 7 Letras, 2013.

Em um artigo publicado em 2010, na revista Alea, João Camillo Penna se propõe a estudar um lugar-comum da crítica na discussão da obra de Clarice Lispector, as "suas epifanias". Para isso, mostra como tal perspectiva crítica se estabelece, discute tanto o uso mais recente do conceito, em Joyce, por exemplo, quanto a sua teorização na filosofia de Tomás de Aquino, indica como a própria escritora sinaliza a seus leitores esse caminho e, depois, no exame cuidadoso de seus textos, desmonta tudo, constatando a conveniência de deixar de lado uma chave interpretativa gasta e sugerindo uma nova porta de entrada analítica.

Descrito assim, o procedimento parece adequado e correto. Só que ele é mais do que isso. Como qualquer leitor do ensaio logo percebe, há ali um rigor muito pouco usual, uma espécie de obsessão com o conceito que não aceita qualquer saída fácil, que não hesita em conduzir o raciocínio aonde quer que ele precise ir.

Em Escritos da sobrevivência, ${ }^{2}$ reunião de textos que lidam com diferentes formas de relação entre a arte e a violência nas últimas décadas, entra em operação a mesma lógica, aqui levada à quase vertigem. Os elos conceituais invocam as mais variadas disciplinas: a literatura, a filosofia, a antropologia, a sociologia, a história, o cinema, o jornalismo são convocados, com cuidado e urgência, para lidar com um assunto que é obviamente transversal, o que implica, de novo, a impressão de que é quase "natural" que o livro seja como é. A impressão é falsa.

O volume é composto por oito ensaios. No primeiro, também o mais longo e ambicioso deles, "Sobre viver (Giorgio Agamben e Primo Levi)", a discussão gira em torno do estudo do filósofo italiano O que resta de Auschwitz. O arquivo e a testemunha. Após expor longamente o argumento da obra, num movimento característico, João Camillo Penna escreve:

1. PEnNA, João Camillo. “O nu de Clarice Lispector”, revista Alea, v. 12, n. 1, jan.-jun. 2010.

2. Id. Escritos da sobrevivência. Rio de Janeiro: 7 Letras, 2013. As citações do livro, a seguir, trarão apenas o número da página indicado. 
Permanece, no entanto, uma dúvida.

O projeto agambeniano de tratar como imanência o testemunho dos campos de extermínio, e especificamente o de Primo Levi, é uma tentativa impressionante de retornar, por assim dizer, à cena originária das políticas humanitárias, reconstituindo a separação soberana entre vida nua e soberania, que o campo de concentração administra, e a que o humanitarismo remete - como antídoto, no entanto, irremediavelmente cúmplice. Entretanto, resta saber se Agamben, ao procurar afastar o fantasma da transcendência humanista e sua 'coisa', a 'vida nua', sob a forma da soberania do direito, não abole, pelo mesmo gesto, qualquer instância judicativa necessária para discernir a barbárie da não barbárie, a justiça do extermínio. Resta saber se, ao distinguir o campo da ética do campo jurídico, moral e religioso, ele não acaba esvaziando a questão ao mesmo tempo jurídica, moral e religiosa do julgamento dos culpados, ou acaba pelo menos nuançando o que não pode ser nuançado, e sobre o qual não pode permanecer nenhuma dúvida. Resta saber se ele, ao partir da representação moderna (kafkiana) do direito como sistema autorreferencial, ao refutar a possibilidade da decisão soberana, refugiando-se na zona flou do indecidível, não abdica de uma prerrogativa essencial da justiça, que é poder identificar os culpados e distribuir as penas. Resta saber, em suma, se ele, ao generalizar a categoria interna ao campo de 'zona cinzenta' descoberta por Primo Levi, não acaba também fazendo-a abarcar os criminosos nazistas, o que seria, no mínimo, uma grande injustiça não só para com Primo Levi, além de uma impropriedade do pensamento (p. 81).

A citação é longa, mas muito representativa. Após o anúncio delicado ("Permanece, no entanto, uma dúvida"), surgem reiterados "resta saber", que remetem ao título do estudo de Agamben e mostram de forma sintetizada e dolorosa (afinal, trata-se ao mesmo tempo de uma "injustiça" e de uma "impropriedade do pensamento" em um tema que dificilmente tolera mais injustiças e impropriedades do pensamento...) esse "resto" que será expandido e dissecado a partir do parágrafo seguinte, que começa com um "Senão vejamos".

O segundo ensaio, "Fala, Rigoberta", continua discutindo a relação entre violência, testemunho, arte e verdade, só que focado agora na especificidade latino-americana, da sua cena inicial, em janeiro de 1969, quando os jurados do Prêmio Casa de las Américas resolvem criar uma categoria especial para o prêmio, que estaria ligada menos a questões estéticas e mais ao processo histórico pelo qual passava a América Latina, até sua suposta superação, como decreta John Beverly, que será então devidamente problematizada.

Do terceiro capítulo em diante, encontramos análises centradas na representação da violência na sociedade brasileira: o massacre do Carandiru e os testemunhos de pre- 
sos em livros e filmes ( $O$ sujeito carcerário), os livros de Hermano Vianna sobre o funk e o samba e a visão "pacificadora" de uma cultura muito mais "vital e terrível" (O encontro e a festa), uma história pavorosa em quatro atos sobre Marcinho VP, que acompanha a sua passagem de pequeno marginal a marginal "midiático" logo assassinado e que deveria ser leitura mais do que obrigatória em qualquer curso de ética de qualquer faculdade de jornalismo do país ("Marcinho VP como personagem"), as "biografias paralelas" de Helinho e Garnizé e o documentário O Rap do Pequeno Príncipe contra as almas sebosas, de Paulo Caldas e Marcelo Luna ("A violência como figura”), o rapper Sabotage, os livros de Marçal Aquino e o cinema de Beto Brant ("Sabotage e a soberania"), o livro/filme Cidade de Deus e o documentário Falcão, meninos do tráfico ("Mediação e inclusão").

Em cada um dos textos, acumulam-se evidências para comprovar uma hipótese de leitura da cultura brasileira contemporânea lançada na introdução, a de que "as mediações que antes existiam [...] entre estratos distintos da sociedade, responsáveis pelas formas culturais reconhecidamente mais bem-sucedidas do Brasil, como Machado, o samba, e o futebol [...]" não conseguem mais dar conta de "um cenário de segmentarização radical, crescente, como a que define a cidade brasileira atual [...]" (p. 24). Decorre daí, dessa falência, serem certos "mediadores" - aqueles que recolhem testemunhos, que autorizam testemunhos, que provocam testemunhos - alguns dos principais personagens da obra, sempre vistos em contraposição àqueles "sujeitos de autonomia cada vez mais precária, dependentes de instâncias constitutivas cada vez mais instáveis, e com dificuldades quase intransponíveis de produzirem-se a si próprios” (p. 33).

Ao se dedicar sua análise, no último capítulo, às etapas de criação do fenômeno literário, cinematográfico e televisivo em que se transformou o projeto "Cidade de Deus", de Paulo Lins, um tipo diferente de arte, portanto, que transcende muito rapidamente seu suporte inicial e se instala em uma rede que se multiplica e intensifica, João Camillo Penna discute exatamente o surgimento no Brasil de um novo tipo de mediação, no qual os sujeitos de dentro desautorizam os sujeitos de fora, "não pedem permissão para falar". Isso não se dá, claramente, sem conflito ou contestação, e é essa história turbulenta, com êxito discutível, que o pesquisador narra e discute nesse ensaio final.

No meio de sua exposição, o autor retoma um artigo de Spivak, "Pode o subalterno falar?". E comenta-o: 
O subalterno, de fato, não fala; ele é constitutivamente incapaz de falar, já que é silenciado pelo aparelho institucional que permite sua voz até quando defende seu direito de fala, na verdade, falando em seu lugar, numa forma de ventriloquismo (p. 282).

Para terminar esta brevíssima e incompleta resenha, cujo objetivo central era apenas chamar a atenção para o conteúdo de um livro que precisa ser lido, gostaria de apontar como a palavra final desse comentário de João Camillo Penna, "ventriloquismo", aparece em outros momentos de seus ensaios. Por exemplo: "O ventriloquismo jornalístico dubla a enunciação do entrevistado, e o dispositivo judicial-policial fala mais alto, cobrindo a sua voz" (p. 198); ou: "[A testemunha sobrevivente] terá que falar enquanto ser ordinário, pelo muçulmano, em fala ventríloqua de seu silêncio" (p. 57).

Essa recorrência me parece significativa porque evidencia o alcance do estudo, que, por um lado, dá ordem e sentido a um cruzamento de referências necessárias para lidar com uma série de fatos culturais de óbvia relevância e difícil compreensão e, por outro, atinge também um ponto específico e nevrálgico do estudo do romance contemporâneo, pelo menos desde a implosão beckettiana do gênero no pós-guerra, que é o lugar profundamente instável e deslocado daquele que fala. Basta mencionar o "pense no ventríloquo", usado por Philip Roth para justificar seu jogo de máscaras e personificações, ou todas as intermináveis variações sobre a questão encetadas por J.M. Coetzee na sua produção ficcional e na sua produção acadêmica, ou ainda o uso da mentira, das atribuições falsas, das repetições modificadas como estratégia narrativa em Ricardo Piglia.

Se o "ventriloquismo" que aparece e reaparece em Escritos da sobrevivência sugere uma voz que surge onde não deveria estar, encobrindo outra voz, ocupando o lugar de outra voz, usurpando outra voz, o romance contemporâneo tematiza movimentos semelhantes, ficcionaliza esses impasses em busca da sua particular "sobrevivência". Enfim, seja pelo que propõe, seja pelo que não propõe, ao menos diretamente, trata-se de um livro fundamental.

Adriano Schwartz é professor de literatura contemporânea da Escola de Artes, Ciências e Humanidades da Universidade de São Paulo. 